\title{
Mammalian mitochondrial DNA replication intermediates are essentially duplex, but contain extensive tracts of RNA/DNA hybrid
}

\author{
Jaakko L. O. Pohjoismäki ${ }^{*}, 1$, J. Bradley Holmes ${ }^{\star}, 2,3$, Stuart R. Wood ${ }^{2}$, Ming-Yao Yang ${ }^{2}$, \\ Takehiro Yasukawa $^{2,4}$, Aurelio Reyes ${ }^{2}$, J. Bailey Laura ${ }^{2}$, Tricia J. Cluett ${ }^{2}$, Steffi Goffart ${ }^{1}$, \\ Smaranda Willcox ${ }^{5}$, Rachel E. Rigby ${ }^{6}$, Andrew P. Jackson 6 , Johannes N. Spelbrink ${ }^{1}$, Jack \\ D. Griffith ${ }^{5}$, Robert J. Crouch ${ }^{3}$, Howard T. Jacobs ${ }^{1}$, and lan J. Holt ${ }^{2}$ \\ ${ }^{1}$ Department of Forensic Medicine and Tampere University Hospital, FI-33014 University of \\ Tampere, Finland Institute of Medical Technology and Tampere University Hospital, FI-33014 \\ University of Tampere, Finland ${ }^{2} \mathrm{MRC}$-Mitochondrial Biology Unit, Wellcome Trust-MRC Building, \\ Hills Road, Cambridge CB2 OXY, UK ${ }^{3}$ Program in Genomics of Differentiation, Eunice Kennedy \\ Shriver National Institute of Health and Human Development, National Institutes of Health, \\ Bethesda, Maryland 20892, USA ${ }^{5}$ Lineberger Comprehensive Cancer Center, University of North \\ Carolina School of Medicine, Mason Farm Road, Chapel Hill, NC 27599, USA ${ }^{6}$ MRC Human \\ Genetics Unit, Western General Hospital, Crewe Road, Edinburgh, EH4 2XU, UK
}

\begin{abstract}
We demonstrate, using transmission electron microscopy and immunopurification with an antibody specific for RNA/DNA hybrid, that intact mtDNA replication intermediates (mtRIs) are essentially duplex throughout their length, but contain extensive RNA tracts on one strand. However, the extent of preservation of RNA in such molecules is highly dependent on the preparative method used. These findings strongly support the strand-coupled model of mtDNA replication involving RNA incorporation throughout the lagging strand (RITOLS).
\end{abstract}

\section{INTRODUCTION}

\begin{abstract}
Mammalian mitochondrial DNA (mtDNA) is a covalently closed circular molecule of approximately $16.5 \mathrm{~kb}$. The mechanism by which it replicates is a subject of intense debate. For almost thirty years mtDNA was believed to replicate via a strand-displacement mechanism first proposed in 1972 (1). Its key feature is continuous synthesis of both strands from physically and temporally distinct initiation sites, accompanied by the formation of long tracts of single-stranded DNA. Based on transmission electron microscopy (TEM) and 5 ' end mapping $(1,2)$, leading (heavy, H) strand DNA synthesis was inferred to initiate at
\end{abstract}

\footnotetext{
(C) 2009 Elsevier Ltd. All rights reserved.

Correspondence to: Ian J. Holt.

${ }^{*}$ Who contributed equally to the work and are here denoted as joint first authors

${ }^{4}$ Present address: Wolfson Institute for Biomedical Research, University College London, The Cruciform Building, Gower Street, London, WC1E, 6BT, UK

Publisher's Disclaimer: This is a PDF file of an unedited manuscript that has been accepted for publication. As a service to our customers we are providing this early version of the manuscript. The manuscript will undergo copyediting, typesetting, and review of the resulting proof before it is published in its final citable form. Please note that during the production process errors may be discovered which could affect the content, and all legal disclaimers that apply to the journal pertain.
} 
several tightly clustered sites in the major non-coding region (NCR), designated $\mathrm{O}_{\mathrm{H}}$. Initiation of second (light, L) strand synthesis was proposed to take place after the leading strand traversed approximately two-thirds of the genome, at a short intergenic spacer designated as the light-strand origin, $\mathrm{O}_{\mathrm{L}}$.

Recently, we have presented evidence supporting alternative models, based on analyses of mitochondrial replication intermediates (mtRIs) separated by neutral two-dimensional agarose gel electrophoresis (2D-AGE). mtRIs derived from different mammalian cell-types were found to have the properties of products of conventional, strand-coupled DNA synthesis (3). Although partially single-stranded (ss) mtRIs were seen in crude preparations of mtDNA (3), mtRIs from sucrose density gradient-purified mitochondria were essentially duplex (4). However, a proportion of mtRIs differed from conventional replication intermediates in that they contained extensive RNA tracts (5), which were later shown to encompass the entire lagging strand (6). These RITOLS intermediates (standing for $\underline{R} N A$ incorporation throughout the lagging strand) were proposed to be replaced by DNA via a maturation step (6).

In subsequent work, atomic force microscopy (AFM) was used to visualize $\mathrm{CsCl}$-banded mtDNA coated with $E$. coli single-stranded binding protein (SSB) (7), DNA molecules with extended single-stranded regions, as predicted by the strand-displacement model (SDM), were observed at high frequency and it was suggested that at least $99.5 \%$ of all $\mathrm{mtRIs}$ arise from SDM. Conversely, it was suggested that the failure to detect these intermediates by 2D-AGE resulted from strand separation (branch migration) during electrophoresis, or some other artifact (7).

In the present work we set out to understand how the data from these different approaches yield such disparate results. We first used TEM to analyze mtRIs prepared by the same methods as for 2D-AGE, comparing samples before and after treatment with RNase $\mathrm{H}$, an enzyme that specifically degrades the RNA strand of RNA/DNA hybrid. Secondly, we employed a monoclonal antibody highly specific for RNA/DNA hybrid to probe the composition of mtRIs. Both methods generated findings fully consistent with the RITOLS model. Analysis of model substrates by 2D-AGE confirmed that RITOLS intermediates migrate distinctly from single-stranded D-loop or R-loop forms. Next we demonstrated that various preparative methods, including $\mathrm{CsCl}$ banding and SSB treatment, lead to systematic loss of RNA from molecules containing RNA/DNA hybrid. Finally, we confirmed that partially single-stranded molecules, created deliberately by RNase $\mathrm{H}$ treatment of otherwise intact mtRIs, do not undergo strand separation during 2D-AGE. Our findings thus support the RITOLS model.

\section{RESULTS}

\section{Electron microscopy of intact $\mathrm{mtRls}$ is consistent with strand-coupled replication involving RNA incorporation on the lagging strand}

To test whether the preparations of mtRIs which we studied earlier by 2D-AGE were fully double-stranded, we carried out TEM on mtDNA extracted from sucrose gradient-purified mitochondria from both human HEK293 cells and mouse liver. Of 1005 mtDNA molecules from HEK293 cells analyzed, 52 were $\theta$ replication intermediates, most of them intact and fully duplex (Fig. 1A, 1B, 1E, Table 1, Suppl. Fig. 1A-E), with replication bubbles of lengths varying up to almost $100 \%$ of the genome. In some cases broken, but fully duplex, $\theta$ molecules were seen (e.g. Suppl. Fig. 1F). In a minority of molecules, short 'collapsed' segments, considered the signature of single-strandedness (9), were seen near one fork, although only one analyzed mtRI appeared to have a long collapsed segment as one branch of a replication bubble (Suppl. Fig. 1G). Similar analysis of mouse liver mtDNA revealed a 
much lower frequency of mtRIs ( 3 out of 600 molecules). Although broken, these again corresponded to fully duplex $\theta$ forms (Fig. 1C, Suppl. Fig. 1H). In contrast, prior treatment with RNase $\mathrm{H}$ generated extensive collapsed segments on the majority of $\theta$ molecules. The tendency of these segments to become tangled prevented definitive interpretation, although forms tentatively interpreted as gapped circles and $\theta$ molecules partially single-stranded on one branch were present. Extensive single-stranded regions were clearly seen in RNase H treated material spread using formamide (Fig. 1E, Suppl. Fig. 1I, 1J), a method which resolves single and double-stranded DNAs.

\section{Immunopurification of mtRls using a monoclonal antibody against RNA/DNA hybrid confirms that they contain extensive RNA tracts}

Mitochondrial replication intermediates are grossly modified by RNase $\mathrm{H}$ treatment, implying they contain lengthy tracts of RNA/DNA hybrid $(5,6)$. To test, by a different approach than the use of RNase $\mathrm{H}$, that mtRIs contain regions of RNA/DNA hybrid, we made use of a monoclonal antibody raised against this class of polynucleotide (10). After confirming its specificity using model substrates (Suppl. Fig. 2), we treated a $B c l$ I digest of mouse liver mtDNA with the antibody prior to 2D-AGE, then probed for the $4.1 \mathrm{~kb} \mathrm{O}_{\mathrm{H}^{-}}$ containing fragment (Fig. 2A). Antibody treatment modified the mobility of the same molecular species that were sensitive to RNase $\mathrm{H}$, indicating the presence of RNA/DNA hybrid. Next we used the antibody to immunopurify mtRIs containing RNA/DNA hybrid from a similar digest (Fig. 2B), and analyzed the bound and unbound material by 2D-AGE. The same molecular species were highly enriched in the bound fraction. Treatment with RNase $\mathrm{H}$ prior to immunopurification (Fig. 2C) confirmed that the unbound material (panel i, ii), was essentially RNase H-resistant, whereas the bound fraction was eliminated by RNase H (panels iii, iv).

\section{Recovery of intact RITOLS intermediates is affected by preparative method}

We previously observed that the recovery of intact RITOLS intermediates was dependent on the method used to prepare mitochondria. Whereas mtRIs from sucrose density-gradient purified mitochondria contained extensive lagging-strand RNA, this was degraded in material prepared from crude mitochondria (5). We therefore set out to test whether other commonly used preparative methods influenced the extent of recovery of mtRIs containing tracts of RNA/DNA hybrid.

Cesium chloride $(\mathrm{CsCl})$ gradients have been used widely to purify DNA, notably for imaging of mtRIs $(1,7,11)$. We therefore compared 2D-AGE profiles of mtDNA purified by $\mathrm{CsCl}$ banding with total nucleic acid extracted from sucrose gradient-purified mitochondria. Two bubble arcs were associated with CsCl-purified mtDNA samples from mouse and rat liver (Fig. 3A-ii, 3B-ii), whereas only one was seen in material from sucrose gradientpurified mitochondria (Fig. 3A-i, 3B-i). However, RNase $\mathrm{H}$ treatment of the latter generated the same two bubble arcs as seen after $\mathrm{CsCl}$ gradient purification (Fig. 3A-iii, 3B-iii). Thus, whilst $\mathrm{CsCl}$ banding is effective at purifying mtDNA, it entails loss of RNA/DNA hybrids associated with replicating molecules. Careful inspection of previously published 2D-AGE analysis of CsCl-banded mtDNA (Suppl. Fig. 3) also reveals evidence for loss of RNA from mtRIs.

To investigate whether the integrity of mtRIs could be affected by incubation with SSB, as commonly used in AFM studies, we tested the effects of SSB from each of two suppliers on a model RNA/DNA hybrid substrate. Surprisingly, the synthetic hybrid was found to be disrupted and the labeled oligoribonucleotide strand degraded to a similar extent as by $E$. coli RNase H (Fig. 3C). The unhybridized oligoribonucleotide was not cleaved by incubation with SSB under identical conditions. We infer that treatment with commercially 
available preparations of SSB efficiently eliminates RNA tracts from molecules containing RNA/DNA hybrid.

\section{Model Substrates}

In order to clarify the mobility of various species resolved by 2D-AGE, synthetic D-loops were generated by extending an annealed primer with Klenow DNA polymerase (Suppl Fig. 4). As predicted, the synthetic D-loops formed an arc that resolved below the standard bubble arc traversed by replicating mtDNA molecules (Suppl Fig. 4C-iv). Moreover, the synthetic D-loops had a similar mobility on $2 \mathrm{D}$ gels to the species previously assigned as partially single-stranded molecules, which appear in mtDNA from crude mitochondrial preparations or in sucrose gradient-purified samples after RNase $\mathrm{H}$ treatment, and which therefore lack an RNA lagging strand (Suppl Fig. 4D). R-loops generated by T7 RNA polymerase, likewise produced an arc resolving below the bubble arc of a similar sized mtDNA fragment (Suppl Fig. 5C). Their identity as R-loops is confirmed by their sensitivity to RNase $\mathrm{H}$ and the fact that their mobility was retarded by the S9.6 antibody that binds to RNA/DNA hybrid (Suppl Fig. 5D and 5E, respectively). Thus, the 2D gel arcs formed by intact mtDNA replication intermediates are not explicable as the products of an expanding D-loop (strand-displacement) mechanism, nor as R-loops formed by transcription, but instead are bona fide duplex.

\section{mtRIs artificially rendered as partially single-stranded show minimal strand separation on 2D-AGE}

Since RITOLS intermediates can be lost during DNA extraction due to a variety of treatments, we next considered the possibility that bona fide mtRIs predicted by the stranddisplacement model (SDM) might themselves be lost systematically during 2D-AGE, as a result of strand separation (branch migration) (Suppl. Fig. 6A, C). To address this issue, we first verified that single-stranded products of strand separation could readily be distinguished from dsDNA on 2D gels, using heat denaturation of DNA marker ladders (Fig. 5A). Next, we deliberately created partially single-stranded forms by RNase $\mathrm{H}$ treatment of material extracted from sucrose density-gradient purified mitochondria (as illustrated in Suppl. Fig. $6 \mathrm{~B}$ ) and subjected them to analysis by 2D-AGE after restriction digestion (Fig. 5B). No arc of ssDNA was detected in untreated material (Fig. 5B-i), and it was only faintly visible after samples were treated with RNase H (Fig. 5B-ii), which modified the slow-moving Y-like $\operatorname{arc}(\mathrm{mSMY})$ as expected. Given that sporadic ribonucleotides are present in both template strands of mammalian mtDNA (12), the exposed single-stranded regions of the mSMY species should be cleaved by single strand-specific ribonucleases, as illustrated in Fig. 5Biii. As predicted, co-incubation of sucrose-gradient purified mtDNA with RNase $\mathrm{H}$ and RNase One ${ }^{\mathrm{TM}}$ obliterated the SMY arc and increased the intensity of the ssDNA arc (Fig. 5B-iv). Thus, even where an ssDNA arc is detected in mammalian mtDNA samples (e.g. from crude mitochondria, Fig. 5C-i) it can arise by RNA degradation rather than branch migration. Treatment of $\mathrm{mtRIs}$ from crude mitochondria with a single strand-specific nuclease (S1) destroyed the ssDNA and mSMY arcs (Fig. 5C-ii).

To extend the analysis to the entire mitochondrial genome, mouse mtDNA was digested with $B l p \mathrm{I}$, which cuts just once, at nucleotide (nt) 511. No arc of ssDNA was seen (Fig. 6Bii), such as would be predicted to arise by branch-migration of partially single-stranded mtRIs (Fig. 6A and 6B-i). Once again, a faint ssDNA arc appeared only after RNase $\mathrm{H}$ treatment (Fig. 6B-iii), which was, as expected, abolished by $\mathrm{S} 1$ nuclease treatment (Fig. 6B-iv). Modifying the 2D-AGE conditions to resolve BlpI products larger than $16 \mathrm{~kb}$ revealed a prominent duplex bubble arc (Fig. $6 \mathrm{C}$-i) spanning almost the entire genome, which was again modified by RNase $\mathrm{H}$ (Fig. 6C-ii) to generate a subsidiary bubble arc that was sensitive to $\mathrm{S} 1$ nuclease (Fig. 6C-iii). In conclusion, partially single-stranded mtRIs 
appear to be stable under standard conditions of 2D-AGE. Their absence from gel images in which fully duplex forms are easily detected is thus meaningful.

\section{Gapped circular mtDNAs result from RNA loss}

The RITOLS mechanism predicts delayed second-strand DNA synthesis (6), but daughter molecules where second-strand DNA synthesis is incomplete will contain RNA tracts on one strand. The extent of the RNA will depend on the sites and timing of maturation (6); typically the last section of the lagging-strand to be matured will be the five kilobases between $\mathrm{O}_{\mathrm{L}}$ and $\mathrm{O}_{\mathrm{H}}$, in the so-called minor arc. Restriction enzymes that do not cut RNA/ DNA hybrid and have sites exclusively in the minor arc should thus give rise to uncut, but fully duplex circular monomers, which RNase $\mathrm{H}$ should then process into gapped circles by elimination of lagging-strand RNA in the unmatured region between $\mathrm{O}_{\mathrm{L}}$ and $\mathrm{O}_{\mathrm{H}}$. In agreement with these predictions, $B l p \mathrm{I}$ digestion of sucrose-gradient purified mouse liver mtDNA yielded a population of circular molecules (Fig. 6C-i), indicative of a failure to cleave at nt 511. RNase $\mathrm{H}$ treatment increased their mobility, yielding an arc of gapped circles (Fig. 6C-ii) that were sensitive to $\mathrm{S} 1$ nuclease (Fig. 6C-iii).

\section{DISCUSSION}

In this study we designed experiments to gain more insight into the mechanisms of replication of mtDNA. Hitherto, the RITOLS model has been based upon the use of a single technique, 2D-AGE $(5,6)$. Here we have used new tools and methods that provide strong support for the RITOLS model. Analysis of mtDNA molecules by TEM revealed fully duplex $(\theta)$ forms (Fig. 1,Suppl Fig. 1,Table 1), as predicted for strand-coupled replication. Moreover, the RITOLS model posits that the lagging-strand initially comprises RNA and therefore RNase $\mathrm{H}$ should modify these $\theta$ structures, which proved to be the case (Fig. 1,Suppl Fig. 1). That many of the mtRIs are not only fully duplex, but contain extensive regions of RNA/DNA hybrid (6) was confirmed by immunopurification with a monoclonal antibody against RNA/DNA hybrid.

Preparations of mtDNA from gradient-purified mitochondria contain only fully duplex mtRIs. These are distinguishable from partially single-stranded (D-loop or R-loop) forms on 2D gels, based on experiments with model substrates (Suppl. Fig. 4, Fig. 5). The absence of partially single-stranded intermediates is not due to their systematic loss by strand separation during 2D-AGE, since the ssDNA products thereof were not detected, even when partially single-stranded forms were created deliberately by RNase $\mathrm{H}$ treatment of otherwise intact material (Fig. 5, Fig. 6). The only exception would appear to be 7S DNA of the mitochondrial D-loop (5). However, this may be released in vivo by a natural stranddisplacement mechanism.

\section{CsCl banding and SSB treatment compromize the recovery of intact mtRls}

Although intact mtRIs are fully duplex, partially single-stranded forms can arise during sample preparation by a variety of treatments, including $\mathrm{CsCl}$ banding and SSB treatment, as well as the use of crude mitochondria. Direct addition of $\mathrm{CsCl}$ to mitochondrial lysates does not reveal a measurable RNase $\mathrm{H}$ activity (7). Moreover, RNA/DNA hybrids are stable to banding in $\mathrm{Cs}_{2} \mathrm{SO}_{4}$ for extended times, at least when the RNA is very long (15). Nevertheless, $\mathrm{CsCl}$ banding in the presence of ethidium bromide results in loss of RNA segments from mtRIs (Fig. 3,Suppl. Fig. 3). Previous studies of mtRIs using electron microscopy support this conclusion. After $\mathrm{CsCl}$ banding virtually all replicating molecules had extensive single-stranded regions (1-7), whereas material analysed without $\mathrm{CsCl}$ purification (16,17), as in our own study (Fig. 1, Suppl. Fig. 1, Table 1), contained mainly or exclusively duplex forms. 
Two commercially available preparations of SSB were found to have RNase H-like activity (Fig. 4). Decoration of mtRIs with SSB prior to AFM should thus systematically replace hybridized RNA with SSB, especially in light of the cooperative binding properties of SSB. It is therefore not possible to use this method to distinguish between different mtDNA replication models.

\section{Independent evidence for RNA/DNA hybrid tracts in mtRIs supports the RITOLS model}

The use of commercial preparations of RNase $\mathrm{H}$ to probe the structure of mtRIs is open to the criticism that the enzyme may have been contaminated with other, unknown activities, as was the case with SSB. To meet this criticism, we employed a completely different tool to probe for hybridized RNA tracts in mtRIs, namely a monoclonal antibody specific for RNA/ DNA hybrid (10), which has no effect on ssDNA. Two specific classes of mtRI were bound by this antibody, namely the bubble arc and the so-called 'slow-moving Y-like arcs' (Fig. 2). The former represents molecules in which replication has initiated near to $\mathrm{O}_{\mathrm{H}}$ and is proceeding unidirectionally towards the other end of the fragment. They correspond with an early step in the replication process. The finding that they are systematically bound by the antibody is consistent with the idea that the provisional, RNA lagging strand is laid down immediately as the replication fork advances. The slow-moving Y-like arcs represent mtRIs in which the growing replication bubble has progressed beyond the $B c l$ site at nt 12,028 , but in which the restriction site at this position (as well as others further downstream) is not cut due to the presence of RNA/DNA hybrid. These molecular species are avidly bound by the antibody (Fig. 2), implying that the replacement of the RNA lagging-strand by DNA frequently commences only after the replication fork has traversed a large fraction of the genome. In contrast, the standard Y-arc, representing molecules in which the restriction site at nt 12,028 is cleaved, was not purified by the antibody against RNA/DNA hybrid, consistent with it being composed essentially of pure dsDNA as proposed previously (6).

\section{Mitochondrial RNase $\mathbf{H}$ activity}

The loss of RNA segments from mtRIs during extraction from crude mitochondria implies that an RNase H-like activity is present. However, this RNA loss can be minimized by prior sucrose density-gradient purification of the mitochondria (5), indicating that it is mainly due to an extramitochondrial contaminant. Cerritelli et al. (18) reported that RNase H1 localizes to both nucleus and mitochondria and that knockout of the gene in the mouse leads to developmental arrest at embryonic day E8.5, with concomitant failure to replicate mtDNA (18). Furthermore, some RNase H activity can be detected in lysates from purified mitochondria (19), where it may be required for the processing or maturation of RITOLS intermediates. Nevertheless, since we are able to isolate intact RITOLS intermediates from gradient-purified mitochondria, we propose that intramitochondrial RNase $\mathrm{H}$ must be carefully regulated or compartmentalized in vivo, rather than being constitutively active.

\section{RITOLS and transcription}

One suggestion that has been made to account for the presence of mtDNA molecules containing segments of RNA/DNA hybrid is that these may be transcription rather than replication complexes (14). However, simple transcription complexes typically have only a short R-loop near to the site of transcription $(21,22)$, and other transcriptionally (or cotranscriptionally) induced R-loops give rise to a displaced single-strand of DNA (23). Recently, R-loops associated with mouse L cell mtDNA have been described and it was suggested that they might confound 2D-AGE analysis of mtRIs (24). However, as we demonstrate using model substrates (Suppl. Fig. 5), such R-loops migrate differently on 2D gels than the duplex bubble arcs formed by mtRIs. For transcription to account for a duplex bubble arc, the transcriptional template would need to be a partially single-stranded replication intermediate that was continuously rendered duplex by new transcription as the 
replication fork advances. This corresponds exactly with the RITOLS model of mtDNA replication. Transcripts that remain associated with mtDNA following transcription and RNA processing could provide the raw material for creation of the provisional RNA lagging-strand of RITOLS intermediates. Further processing thereof could create short RNA primers for synthesis of the definitive lagging-strand, as is the case for ColE1 plasmid replication in E. coli (25) and synthesis of the second strand of retroviral DNA (26).

\section{Open issues: one mechanism or two?}

The physiological fate of RITOLS intermediates and their relationship to lagging-strand priming remain to be determined, as does the precise mechanism by which the provisional lagging-strand RNA is laid down as the replication fork advances. An additional question concerns the provenance and fate of those mtRIs composed entirely of dsDNA, i.e. which are refractory to digestion with RNase $\mathrm{H}$, are not immunopurified by the antibody to RNA/ DNA hybrid, and are associated with bidirectional initiation in a broad zone downstream of $\mathrm{O}_{\mathrm{H}}(27-28)$.

We have identified several contexts in which the RNA-containing mtRIs become depleted, whilst those comprising dsDNA are correspondingly increased, including recovery from drug-induced mtDNA depletion (29), over-expression of TFAM (30) and expression of dominant-negative variants of the mitochondrial DNA helicase Twinkle (31). Arrest or slowing of leading-strand fork progression may be a common theme, suggesting that the abundance of mtRIs composed only of dsDNA is simply determined by the balance between the rates of leading-strand fork advance and lagging-strand maturation. In turn, this implies that they are primarily or exclusively, maturation products of RITOLS intermediates. On the other hand, the existence, in unperturbed cells, of two radically different classes of mtRIs (those with long tracts of RNA/DNA hybrid versus those with no appreciable RNA) suggests that they arise by distinct mechanisms; especially as the initiation sites of mtRIs comprising pure DNA have different map positions to those associated with RITOLS replication $(6,27,28)$. Therefore, we suggest that conventional leading and lagging-strand DNA synthesis occurs in parallel with RITOLS replication in mammalian mitochondria.

\section{MATERIALS AND METHODS}

\section{Mitochondrial DNA preparation}

The isolation of mitochondria by sucrose density-gradient purification and of mtDNA from HEK293 cells was as described previously (31). Mitochondria and mtDNA of mouse, rat and chick liver were isolated by differential centrifugation and sucrose step-gradient centrifugation, followed by proteinase $\mathrm{K}$ digestion and phenol-chloroform extraction, as previously $(5,6,25)$. Crude mouse mtDNA was isolated similarly, but without the sucrose gradient step (5). Further purification of mtDNA on $\mathrm{CsCl}-\mathrm{EtBr}$ gradients was as described previously $(7,11)$. Fractions were collected and dialyzed twice against one 1 volume of STE buffer in Slide-a-lyzer 7K cassettes (Pierce).

\section{Purification of S9.6 monoclonal antibody}

Crude supernatant from hybridoma cells expressing the S9.6 hybrid antibody (10) was purified using a recombinant protein $\mathrm{A} / \mathrm{G}$ spin column (Pierce) to a final concentration of $0.5 \mathrm{mg} / \mathrm{ml}$.

\section{Immunopurification of RNA/DNA Hybrid}

$100 \mu \mathrm{l}$ of Protein $\mathrm{G}$ magnetic beads (Invitrogen), washed three times with $0.1 \mathrm{M}$ sodium citrate $\mathrm{pH} 5.0$, were re-suspended in $50 \mu 1$ of $0.5 \mathrm{mg} / \mathrm{ml}$ antibody solution and incubated at 4 ${ }^{\circ} \mathrm{C}$ with gentle rolling for $1 \mathrm{~h}$. The beads were washed three times with wash buffer $(10 \mathrm{mM}$ 
HEPES-NaOH, $100 \mathrm{mM} \mathrm{NaCl}, 10 \mathrm{mM}$ EDTA, $\mathrm{pH}$ 7.2), and $30 \mu \mathrm{l}$ of mtDNA solution was added, containing between 15 and $30 \mu \mathrm{g} B c l$ I-digested total nucleic acid resuspended in 10 $\mathrm{mM}$ HEPES-NaOH, $\mathrm{pH}$ 7.2. Following overnight incubation at $4{ }^{\circ} \mathrm{C}$ with gentle rolling, the supernatant was saved and combined with the first $200 \mu \mathrm{l}$ wash as the unbound fraction. Beads were washed 3 times more with $500 \mu \mathrm{l}$ wash buffer followed by two elutions in 200 $\mu 1$ wash buffer plus $0.6 \%$ SDS. The elutions were combined and, in parallel with the unbound material, treated with proteinase $\mathrm{K}(1.92 \mathrm{mg} / \mathrm{ml})$ for $3 \mathrm{~h}$ at $37^{\circ} \mathrm{C}$, followed by phenol-chloroform extraction and isopropanol precipitation.

\section{DNA modification, 2D-AGE and hybridization}

Mitochondrial DNA modification, separation and hybridization were performed as described previously $(5,6,25)$. Restriction enzyme (New England Biolabs) and nuclease treatments (Promega) were performed on $3 \mu \mathrm{g}$ aliquots of purified mitochondrial nucleic acid, under conditions recommended by the manufacturer. Unless otherwise stated, RNase $\mathrm{H}$ treatment was $1 \mathrm{U}$ for $30 \mathrm{~min}$ at $37^{\circ} \mathrm{C}$, RNase One $\mathrm{TM}^{\mathrm{TM}}$ treatment was $1 \mathrm{U}$ for $5 \mathrm{~min}$ at $37^{\circ} \mathrm{C}$, and $\mathrm{S} 1$ nuclease treatment was $1 \mathrm{U}$ for $1 \mathrm{~min}$ at $37^{\circ} \mathrm{C}$. For EMSA with the S9.6 monoclonal antibody, restriction digests were phenol-chloroform extracted, ethanol precipitated and resuspended in $30 \mu 110 \mathrm{mM}$ HEPES-NaOH, pH 7.2. Before loading the first dimension gel, $2.5 \mu \mathrm{g}$ antibody was added to the samples and left at room temperature for $15 \mathrm{~min}$. Neutral 2D-AGE was performed by the standard method (32) for fragments of 3-5 kb and by a modified procedure (33) for fragments larger than $5 \mathrm{~kb}$. Southern blots of 2D gels were hybridized to radiolabeled probes (Ready-To-Go DNA labeling beads, GE Healthcare) for specific regions of vertebrate mtDNA (see below) as previously (6). Filters were exposed to $\mathrm{X}$-ray film or phosphorimager screens and developed after 0.5-7 days.

\section{Radiolabeled mtDNA probes}

Fragments of mtDNA were amplified using the following pairs of oligonucleotide primers (Sigma-Genosys, numbered $5^{\prime}$ to $3^{\prime}$ ). Nucleotide numbering is based on the published sequences of mouse (34) and rat (35) mtDNA. The number assigned to each mouse (m) probe is as in the schematic maps shown in the Figures. Mouse mtDNA probe m1: CTAGGAGGTGTCCTAGCCTTAATC and CGATAACGCATTTGATG-GCCCTG, nt 15,007-15,805; probe m4: ACGCCTAATCAACAACCGTCTCC and CATGGACTTGGATTAACTATGTGATATGC, nt 8,031-8,625; probe m12: CAATATATATACCATGAATATTAT and CCTTAGGTGATTGGGTTTTGCGGA, nt 15,511-16,034. Rat mtDNA, probe r1: ACCTACTAGGAGACCCAGACA and CCTGAGAAGACTGACTCTTCA, nt 14,866-15,331.

\section{Single-stranded DNA markers for 2D-AGE}

To produce a ssDNA arc on a 2D agarose gel, $1 \mathrm{~kb}$ DNA ladder (Invitrogen) was denatured by heat at $95^{\circ} \mathrm{C}$ for $3 \mathrm{~min}$, flash-frozen (ethanol-dry ice) and run on a standard 2D gel together with the double-stranded (undenatured) DNA ladder.

\section{Preparation of RNA/DNA hybrid}

A 46 nt RNA polynucleotide (5'-UUGUUAUUAUUAUGUCCUACAAGCAUUAAUUAAUUAACACACUUU-3') and 93 nt DNA polynucleotide (5'-CTCGAGGGAACCGGTGGAGCTGGCGATTACAAGGACGACGATGACAAGGGCGGAGCCG CTGGACATCACCATCACCATCACTGATGAGGGCCC-3'), were 5' end-labeled using T4 polynucleotide kinase and [ $\left.\gamma^{32} \mathrm{P}\right]$-ATP (GE Healthcare), then purified from unincorporated ${ }^{32} \mathrm{P}$ using a G-50 mini-column (GE Healthcare). The RNA was annealed to a complementary $46 \mathrm{nt}$ DNA in $250 \mathrm{mM}$ Tris-Cl, $\mathrm{pH} 7.9$ by heating at $95^{\circ} \mathrm{C}$ for $3 \mathrm{~min}$, 
followed by cooling to $75{ }^{\circ} \mathrm{C}$ at $0.05{ }^{\circ} \mathrm{C} / \mathrm{s}$, then to $25^{\circ} \mathrm{C}$ at $0.01{ }^{\circ} \mathrm{C} / \mathrm{s}$. After one hour at 25

${ }^{\circ} \mathrm{C}$, hybrids were further cooled to $4{ }^{\circ} \mathrm{C}$ at $0.01{ }^{\circ} \mathrm{C} / \mathrm{s}$, followed by gel purification.

\section{Electrophoretic Mobility Shift Assay (EMSA) of model substrates}

$10 \mathrm{nM} 5^{\prime}-{ }^{32} \mathrm{P}-$ labeled RNA/DNA hybrid or ssDNA and either 2,500, 500, 50, or $5 \mathrm{ng}$ purified S9.6 antibody (Pierce A/G spin-column) or $1 \mu \mathrm{l}$ of crude supernatant (approximately $0.5 \mathrm{mg} / \mathrm{ml}$ antibody) were incubated in a final volume of $15 \mu \mathrm{l}$ binding buffer (50 mM Tris-HCl, pH 7.9, $50 \mathrm{mM} \mathrm{NaCl}, 10 \%$ glycerol, $0.04 \%$ bromophenol blue, $0.04 \%$ xylene cyanol and $10 \mathrm{mM}$ EDTA when indicated). The incubation was carried out for $10 \mathrm{~min}$ at room temperature, and the material immediately loaded into an $8 \%$ polyacrylamide gel $(0.1 \mathrm{~cm} \times 20 \mathrm{~cm} \times 20 \mathrm{~cm})$ cast and run in $1 \times$ TBE. The gel, pre-cooled overnight to $4{ }^{\circ} \mathrm{C}$, was pre-run for $60 \mathrm{~min}$ at $250 \mathrm{~V}$, followed by electrophoresis of the samples at the same voltage until the bromophenol blue had migrated $10 \mathrm{~cm}$. The gel was dried and exposed for approximately $20 \mathrm{~h}$ to a phosphorimager screen.

\section{Assay of SSB-associated nuclease activities}

A 26 nt RNA oligomer (nt 14741-14766 of mouse mtDNA) was 5' end-labeled using T4 polynucleotide kinase and $\left[\gamma^{32} \mathrm{P}\right]$-ATP (GE Healthcare), then purified from unincorporated ${ }^{32} \mathrm{P}$ using a G-50 mini-column (GE Healthcare). It was annealed to a $110 \mathrm{nt}$ DNA oligomer (nt 14691-14800) by heating to $95^{\circ} \mathrm{C}$ for $5 \mathrm{~min}$ then slowly cooling to $4{ }^{\circ} \mathrm{C}$. The synthetic RNA/DNA hybrid was purified by 1D-AGE and electroeluted using Recochips (TaKaRa). Hybrid was incubated with SSB at weight ratios of 7, 4.5 and 2 to 1 (SSB:hybrid) (GE Healthcare) in binding buffer for $15 \mathrm{~min}$ at $37^{\circ} \mathrm{C}$, as described (11). After fixing, by addition of $0.2 \mu \mathrm{l}$ of $8 \%$ glutaraldehyde, products were separated by $20 \%$ nondenaturing PAGE. Nuclease treatments of the RNA/DNA hybrid were $0.15 \mathrm{U}$ RNase H, 15 min at $37^{\circ} \mathrm{C}$, or $1 \mathrm{U}$ RNase $\mathrm{One}^{\mathrm{TM}}, 5 \mathrm{~min}$ at $37^{\circ} \mathrm{C}$.

\section{Transmission electron microscopy}

Approximately $1 \mu \mathrm{g}$ of mitochondrial nucleic acids prepared from sucrose density gradientpurified mitochondria was treated with $50 \mathrm{U}$ of RNase $\mathrm{I}_{\mathrm{f}}(\mathrm{NEB})$ at $37^{\circ} \mathrm{C}$ for $30 \mathrm{~min}$ in manufacturer's reaction buffer, recovered by phenol-chloroform extraction and ethanol precipitation, and redissolved in TEM grade TE-buffer ( $10 \mathrm{mM}$ Tris- $\mathrm{HCl}, 0.1 \mathrm{mM}$ ETDA, $\mathrm{pH}$ 7.6). An aliquot was further treated with $5 \mathrm{U}$ of RNase $\mathrm{H}$ (Fermentas) at $37^{\circ} \mathrm{C}$ for 30 $\min$ in the manufacturer's recommended buffer, and recovered similarly. Aliquots (0.5-1.0 ng) of RNase-treated mtDNA were directly mounted on parlodium-coated grids with or without the presence of formamide, following the Kleinschmidt procedure $(36,37)$. Imaging and analysis were as described previously (38).

\section{Supplementary Material}

Refer to Web version on PubMed Central for supplementary material.

\section{Acknowledgments}

We thank JiaXiao Shen for technical assistance, and Dr. Susana M. Cerritelli for her critique of the manuscript. The study was funded by the Medical Research Council, Academy of Finland, Juselius Foundation, Tampere University Hospital Medical Research Fund, National Institutes of Health (grant GM31819 and the Intramural Research Program of the Eunice Kennedy Shriver National Institute of Child Health and Human Development) and the European Union (EUMITOCOMBAT project). 


\section{REFERENCES}

1. Robberson DL, Kasamatsu H, Vinograd J. Replication of mitochondrial DNA. Circular replicative intermediates in mouse L cells. Proc Natl Acad Sci USA 1972;69:737-741. [PubMed: 4501588]

2. Clayton DA. Replication of animal mitochondrial DNA. Cell 1982;28:693-705. [PubMed: 6178513]

3. Crews S, Ojala D, Posakony J, Nishiguchi J, Attardi G. Nucleotide sequence of a region of human mitochondrial DNA containing the precisely identified origin of replication. Nature 1979;277:192198. [PubMed: 551247]

4. Holt IJ, Lorimer HE, Jacobs HT. Coupled leading- and lagging-strand synthesis of mammalian mitochondrial DNA. Cell 2000;100:515-524. [PubMed: 10721989]

5. Yang MY, Bowmaker M, Reyes A, Vergani L, Angeli P, Gringeri E, Jacobs HT, Holt IJ. Biased incorporation of ribonucleotides on the mitochondrial L-strand accounts for apparent strandasymmetric DNA replication. Cell 2002;111:495-505. [PubMed: 12437923]

6. Yasukawa T, Reyes A, Cluett TJ, Yang MY, Bowmaker M, Jacobs HT, Holt IJ. Replication of vertebrate mitochondrial DNA entails transient ribonucleotide incorporation throughout the lagging strand. EMBO J 2006;25:5358-5371. [PubMed: 17066082]

7. Brown TA, Cecconi C, Tkachuk AN, Bustamente C, Clayton DA. replication of mitochondrial DNA occurs by strand displacement with alternative light-strand origins, not via a strand-coupled mechanism. Genes Develop 2005;19:2466-2476. [PubMed: 16230534]

8. Robberson DL, Clayton DA. Replication of mitochondrial DNA in mouse L cells and their thymidine kinase ${ }^{-}$derivatives: displacement replication on a covalently closed circular template. Proc Natl Acad Sci USA 1972;69:3810-3814. [PubMed: 4509344]

9. Dawid IB, Wolstenholme DR. Ultracentrifuge and electron microscope studies on the structure of mitochondrial DNA. J Mol Biol 1967;28:233-245. [PubMed: 4293206]

10. Boguslawski SJ, Smith DE, Michalak MA, Mickelson KE, Yehle CO, Patterson WL, Carrico RJ. Characterization of monoclonal antibody to DNA.RNA and its application to immunodetection of hybrids. J Immunol Methods 1986;89:123-130. [PubMed: 2422282]

11. Tapper DP, Van Etten RA, Clayton DA. Isolation of mammalian mitochondrial DNA and RNA and cloning of the mitochondrial genome. Methods Enzymol 1983;97:426-434. [PubMed: 6197614]

12. Grossman LI, Watson R, Vinograd J. The presence of ribonucleotides in mature closed-circular mitochondrial DNA. Proc Natl Acad Sci USA 1973;70:3339-3343. [PubMed: 4202844]

13. Clayton DA. Replication of animal mitochondrial DNA. Cell 1982;28:693-705. [PubMed: 6178513]

14. Bogenhagen DF, Clayton DA. The mitochondrial DNA replication bubble has not burst. Trends Biochem Sci 2003;28:357-360. [PubMed: 12878002]

15. Dunn K, Griffith JD. The presence of RNA in a double helix inhibits its interaction with histone protein. Nucleic Acids Res 1980;8:555-566. [PubMed: 6160477]

16. Kirschner RH, Wolstenholme DR, Gross NJ. Replicating molecules of circular mitochondrial DNA. Proc Natl Acad Sci USA 1968;60:1466-1472. [PubMed: 5244753]

17. Wolstenholme DR, Koike K, Cochran-Fouts P. Single strand-containing replicating molecules of circular mitochondrial DNA. J Cell Biol 1973;56:230-245. [PubMed: 4345165]

18. Cerritelli SM, Frolova EG, Feng C, Grinberg A, Love PE, Crouch RJ. Failure to produce mitochondrial DNA results in embryonic lethality in Rnaseh1 null mice. Mol Cell 2003;11:807815. [PubMed: 12667461]

19. Pileur F, Toulme JJ, Cazenave C. Eukaryotic ribonucleases HI and HII generate characteristic hydrolytic patterns on DNA-RNA hybrids: further evidence that mitochondrial RNase $\mathrm{H}$ is an RNase HII. Nucleic Acids Res 2000;28:3674-3683. [PubMed: 10982891]

20. Belanger KG, Mirzayan C, Kreuzer HE, Alberts BM, Kreuzer KN. Two-dimensional gel analysis of rolling circle replication in the presence and absence of bacteriophage T4 primase. Nucleic Acids Res 1996;24:2166-2175. [PubMed: 8668550]

21. Kumar SA, Krakow JS. Studies on the product binding sites of the Azotobacter vinelandii ribonucleic acid polymerase. J Biol Chem 1975;250:2878-2884. [PubMed: 1123330] 
22. Tahirov TH, Temiakov D, Anikin M, Patlan V, McAllister WT, Vassylyev DG, Yokoyama S. Structure of a T7 RNA polymerase elongation complex at 2.9 A resolution. Nature 2002;420:4350. [PubMed: 12422209]

23. Yu K, Chedin F, Hsieh CL, Wilson TE, Lieber MR. R-loops at immunoglobulin class switch regions in the chromosomes of stimulated B cells. Nat Immunol 2003;4:442-451. [PubMed: 12679812]

24. Brown TA, Tkachuk AN, Clayton DA. Native R-loops persist throughout the mouse mitochondrial DNA genome. J Biol Chem 2008;283:36743-36751. [PubMed: 18986989]

25. Dasgupta S, Masukata H, Tomizawa J. Multiple mechanisms for initiation of ColE1 DNA replication: DNA synthesis in the presence and absence of ribonuclease H. Cell 1987;51:11131122. [PubMed: 2446774]

26. Schultza SJ, Champoux JJ. RNase H activity: Structure, specificity, and function in reverse transcription. Sharon J. Virus Research 2007;134:86-103.

27. Bowmaker M, Yang MY, Yasukawa T, Reyes A, Jacobs HT, Huberman JA, Holt IJ. Mammalian mitochondrial DNA replicates bidirectionally from an initiation zone. J Biol Chem 2003;278:50961-50969. [PubMed: 14506235]

28. Reyes A, Yang MY, Bowmaker M, Holt IJ. Bidirectional replication initiates at sites throughout the mitochondrial genome of birds. J Biol Chem 2005;280:3242-3250. [PubMed: 15557283]

29. Yasukawa T, Yang MY, Jacobs HT, Holt IJ. A bidirectional origin of replication maps to the major noncoding region of human mitochondrial DNA. Mol Cell 2005;18:651-662. [PubMed: 15949440]

30. Pohjoismäki JL, Wanrooij S, Hyvärinen AK, Goffart S, Holt IJ, Spelbrink JN, Jacobs HT. Alterations to the expression level of mitochondrial transcription factor A, TFAM, modify the mode of mitochondrial DNA replication in cultured human cells. Nucleic Acids Res 2006;34:5815-5828. [PubMed: 17062618]

31. Wanrooij S, Goffart S, Pohjoismäki JL, Yasukawa T, Spelbrink JN. Expression of catalytic mutants of the mtDNA helicase Twinkle and polymerase POLG causes distinct replication stalling phenotypes. Nucleic Acids Res 2007;35:3238-3251. [PubMed: 17452351]

32. Friedman KL, Brewer BJ. Analysis of replication intermediates by two-dimensional agarose gel electrophoresis. Methods Enzymol 1985;262:613-627. [PubMed: 8594382]

33. Krysan PJ, Smith JG, Calos MP. Autonomous replication in human cells of multimers of specific human and bacterial DNA sequences. Mol Cell Biol 1993;13:2688-2696. [PubMed: 8386315]

34. Bayona-Bafaluy MP, Acin-Perez R, Mullikin JC, Park JS, Moreno-Loshuertos R, Hu P, PerezMartos A, Fernandez-Silva P, Bai Y, Enriquez JA. Revisiting the mouse mitochondrial DNA sequence. Nucleic Acids Res 2003;31:5349-5355. [PubMed: 12954771]

35. Gadaleta G, Pepe G, De Candia G, Quagliariello C, Sbisa E, Saccone C. The complete nucleotide sequence of the Rattus norvegicus mitochondrial genome: cryptic signals revealed by comparative analysis between vertebrates. J Mol Evol 1989;28:497-516. [PubMed: 2504926]

36. Davis RW, Davidson N. Electron-microscopic visualization of deletion mutations. Proc Natl Acad Sci USA 1968;60:243-250. [PubMed: 5241526]

37. Thresher R, Griffith J. Electron microscopic visualization of DNA and DNA-protein complexes as adjunct to biochemical studies. Methods Enzymol 1992;211:481-490. [PubMed: 1406322]

38. Fouche N, Ozgur S, Roy D, Griffith JD. Replication fork regression in repetitive DNAs. Nucleic Acids Res 2006;34:6044-6050. [PubMed: 17071963] 


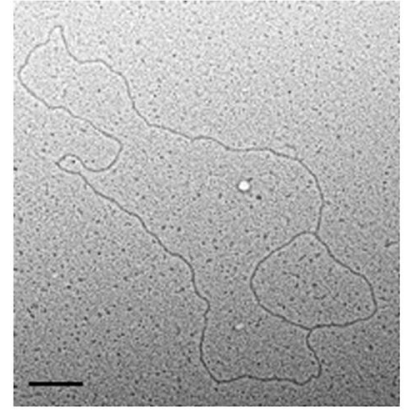

HEK

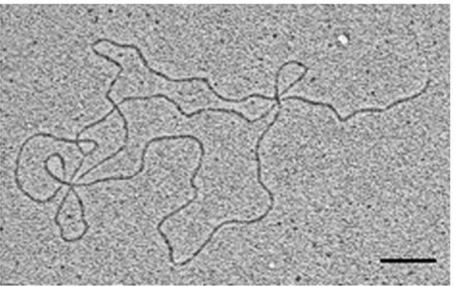

Mouse liver, formamide
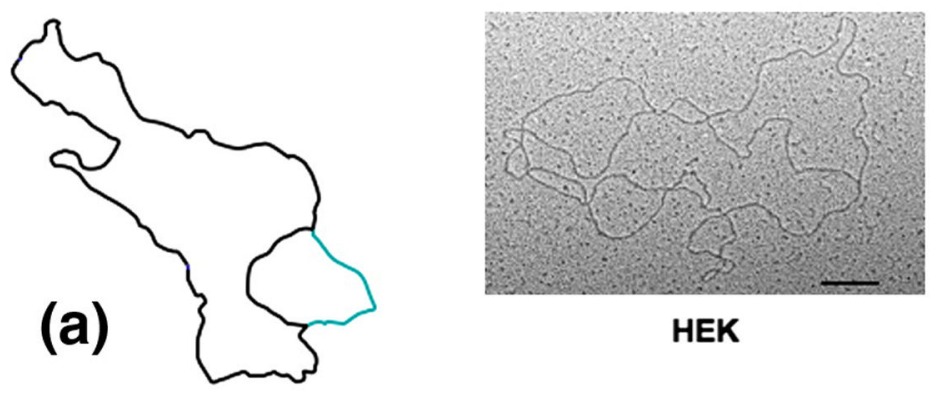

HEK
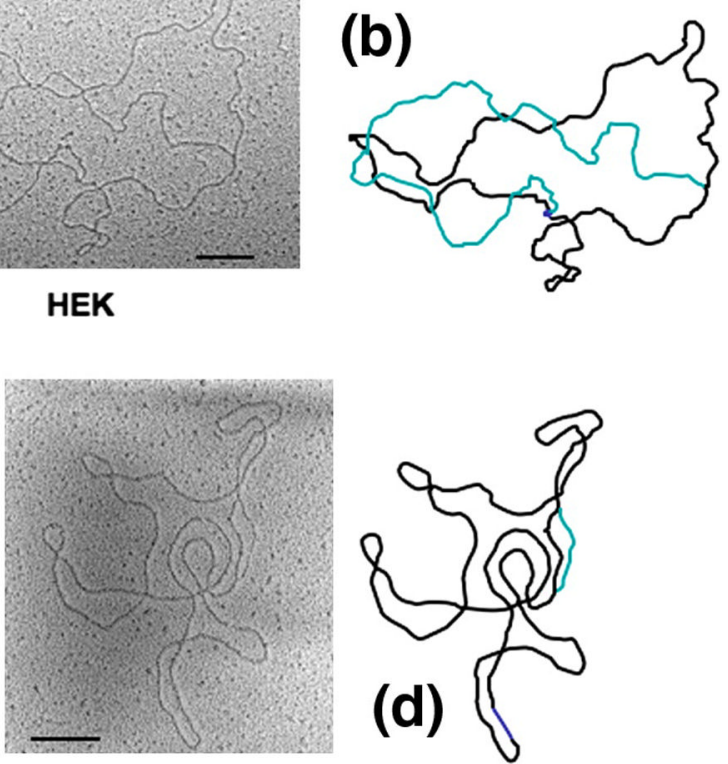

HEK, formamide
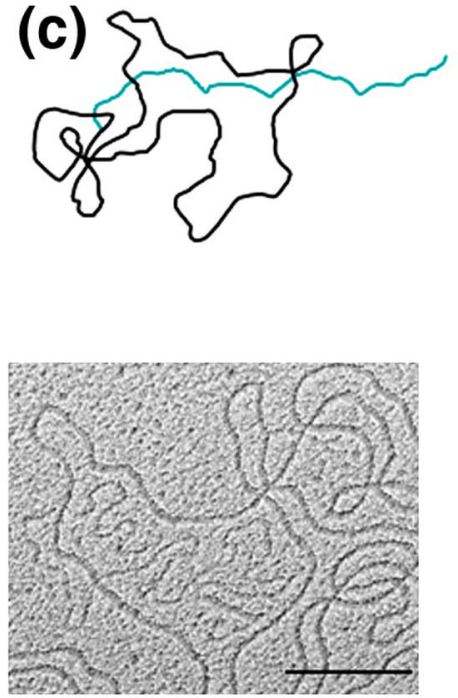

HEK, RNase $\mathrm{H}$, formamide

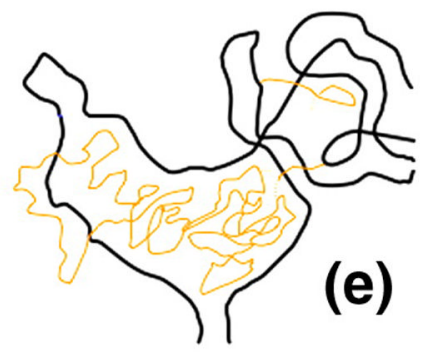

Figure 1. TEM of duplex mtRIs from sucrose gradient-purified mitochondria

Panels A, B, D and E from HEK293 cells, panel C from mouse liver. Scale bars represent $200 \mathrm{~nm}$. Interpretations alongside show duplex segments delineating an entire $16 \mathrm{~kb}$ circle in black, with the alternate branch of replication bubbles in red. A, B, D: examples of fully duplex $\theta$-forms seen without $(\mathrm{A}, \mathrm{B})$ or with $(\mathrm{C}, \mathrm{D})$ formamide spreading. $\mathrm{E}$ : formamide spreading after RNase $\mathrm{H}$ treatment revealed extensive single-stranded regions (orange). For further examples see Suppl. Fig. 1, plus full data compiled in Table 1. 
(a)
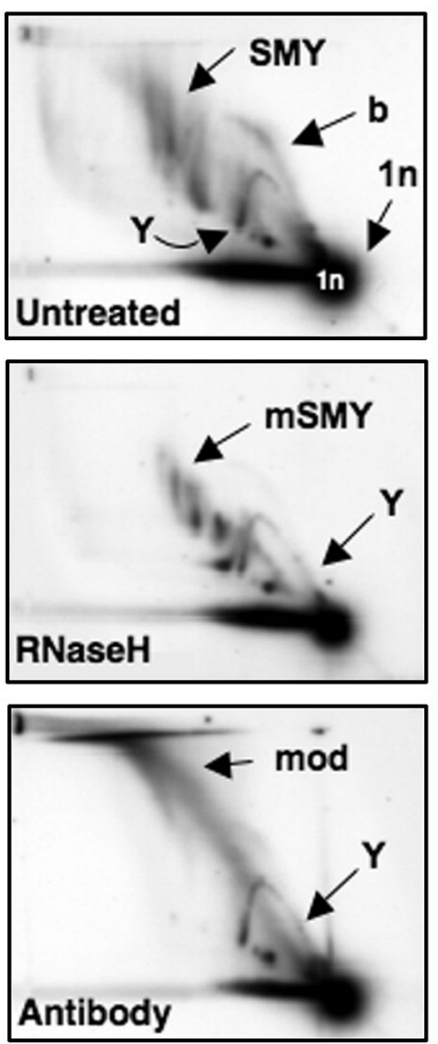

(b)
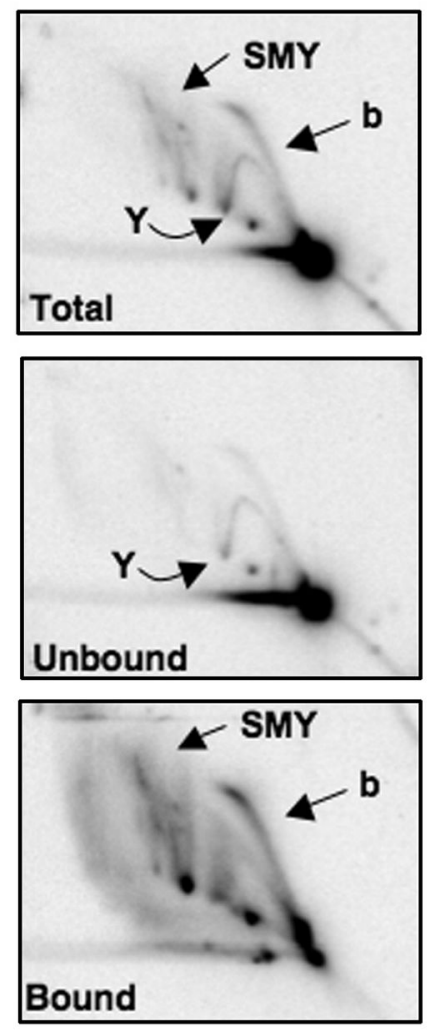

Immunopurification

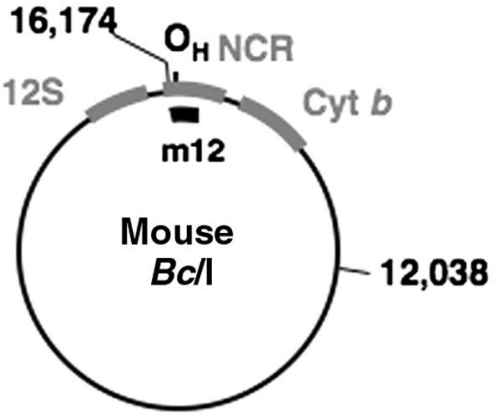

(c)

Untreated
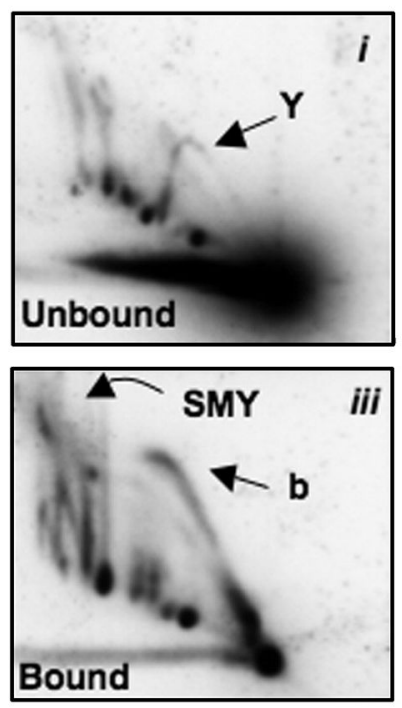

Unbound

RNase H
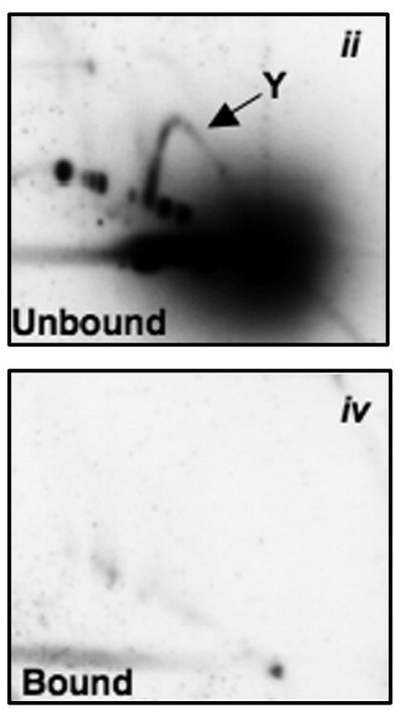

Immunopurification \pm RNase $\mathbf{H}$

Figure 2. Immunopurification of mtRIs with a monoclonal antibody against RNA/DNA hybrid All panels are 2D-AGE of $B c l$-digested mouse liver mtDNA, probed for the $4.1 \mathrm{~kb} \mathrm{O}_{\mathrm{H}^{-}}$ containing fragment (probe m12). 1n - unit-length (unreplicated) fragment, b - bubble arc, SMY - slow-moving Y-like arc, Y - Y arc, mSMY - modified slow-moving Y-like arc, mod - material whose mobility is modified by binding to the antibody. For fuller explanation of terminology see Suppl. Data. (A) The digest was either untreated, digested with RNase H or reacted with the antibody in an EMSA experiment prior to electrophoresis. Antibody treatment modified the mobility of the same species that were sensitive to RNase $\mathrm{H}$, i.e. the bubble arc and SMY arcs, whereas the standard Y-arc was comparatively unaffected. This indicates that the bubble and SMY arcs, which represent 'early' replication intermediates where the leading strand has either not yet traversed the restriction site bounding the fragment, or has passed it leaving an undigestible site, contain extensive regions of RNA/DNA hybrid. Conversely, the standard Y-arc, representing molecules where the lagging DNA strand has been synthesized across the site, contains relatively little RNA/ DNA hybrid. (B) Immunopurification of species containing RNA/DNA hybrid. Comparing bound and unbound fractions with each other and with the same material prior to immunopurification (total), the unbound fraction consisted mainly of the standard Y-arc, whereas the bubble arc and SMY arcs were highly enriched in the bound fraction. This is consistent with the results of the EMSA experiment (panel A). (C) Prior to immunopurification, the sample was either digested (or not) with RNase H. RNase H pre- 
treatment destroyed all of the bound material (panel iv), confirming the specificity of the antibody. Similar findings were obtained if the samples were treated with RNase $\mathrm{H}$ after immunopurification (not shown). The map (left) indicates the digestion sites, probe location and relevant surrounding features of mouse mtDNA (12S - 12S rRNA gene, NCR - noncoding region, Cyt $\mathrm{b}$ - cytochrome $b$ gene, grey bars). 
(a)
$\mathrm{CsCl}$

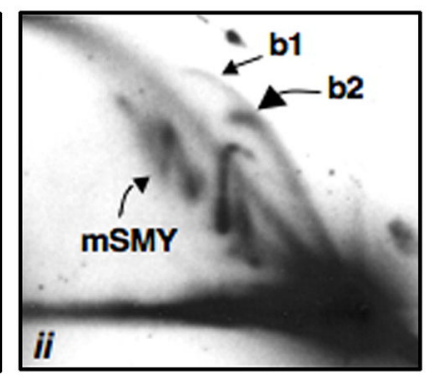

$\mathrm{CsCl}$

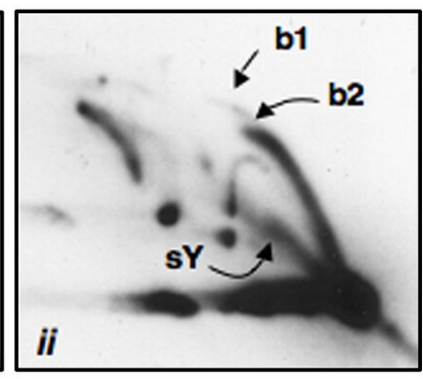

RNase H

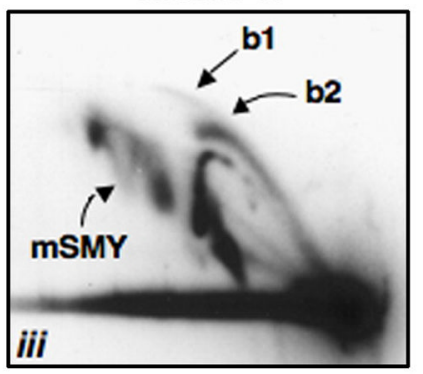

RNase $\mathrm{H}$

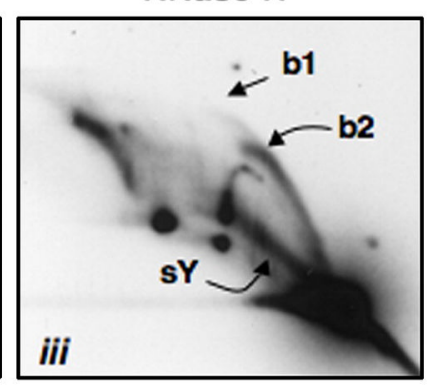

b2

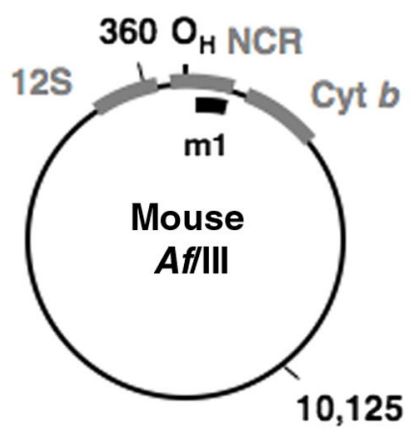

10,125 (b)

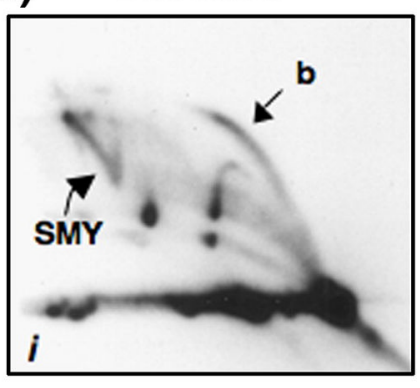

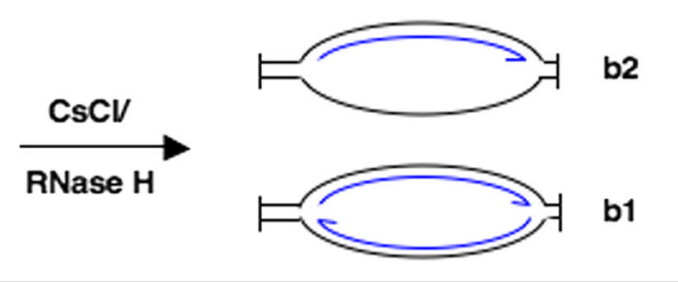
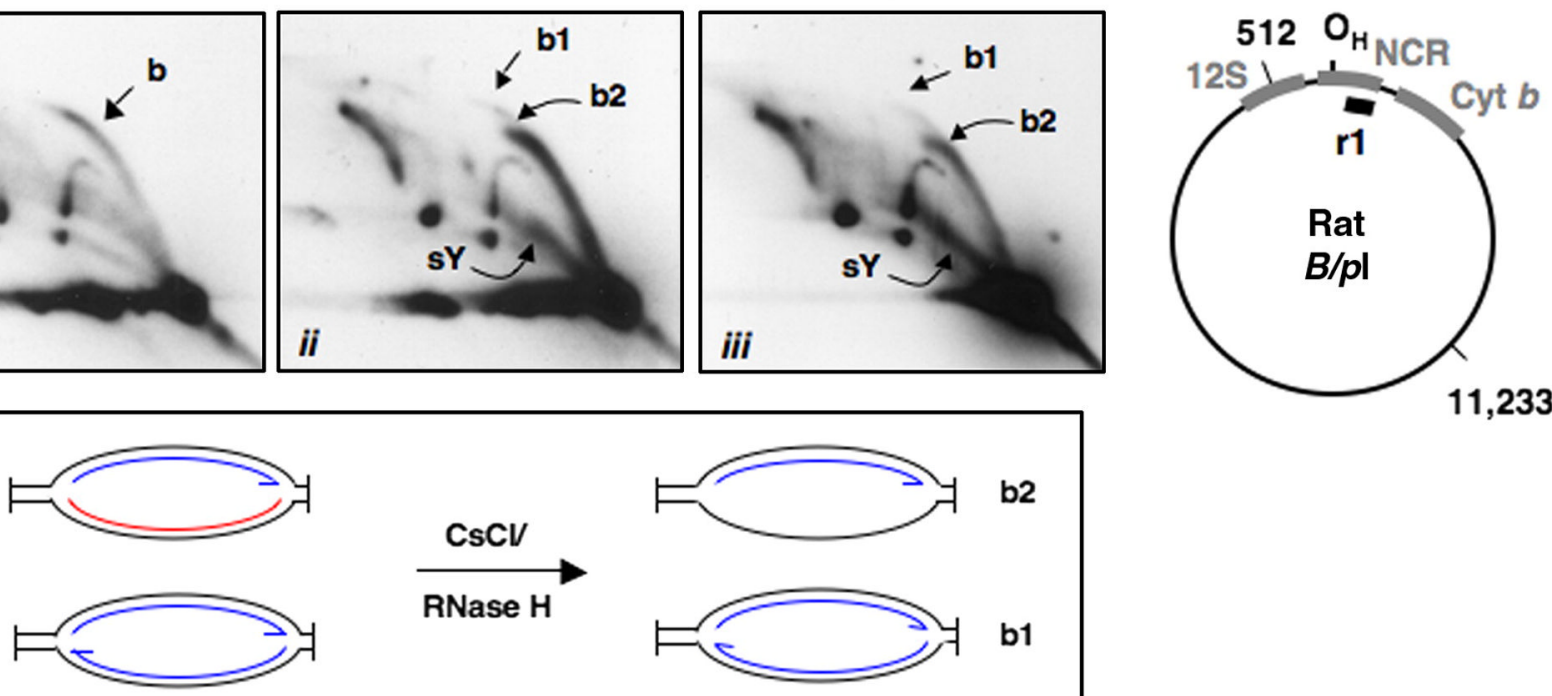

Figure 3. CsCl banding compromises mtDNA quality

(A) 2D-AGE of AflIII-digested mouse liver mtDNA, extracted from sucrose density gradient purified-mitochondria, probed for the $6.5 \mathrm{~kb} \mathrm{O}_{\mathrm{H}^{-}}$-containing fragment. (B) 2D-AGE of BlpIdigested rat liver mtDNA, extracted from sucrose density gradient purified-mitochondria, probed for the 5,579 bp $\mathrm{O}_{\mathrm{H}^{-}}$-containing fragment. Panels $i$ - no further treatment; panels $i i-$ mtDNA purified by $\mathrm{CsCl}$ banding before digestion; panels $i i i-m t D N A$ treated for 5 min with $0.1 \mathrm{U}$ RNase $\mathrm{H}$ at $37^{\circ} \mathrm{C}$ following restriction digestion. $\mathrm{b}$ - bubble arc, resolved by RNase $\mathrm{H}$ or $\mathrm{CsCl}$ banding into an RNase H-resistant bubble arc b1, plus a retracted, RNase H-modified bubble arc b2, as described previously by Yasukawa et al. (6), and as illustrated in the diagram below the gel panels (nascent DNA as blue arrows, provisional RNA laggingstrand in red). The retracted bubble arc b2 created by $\mathrm{RNase} \mathrm{H}$ treatment or $\mathrm{CsCl}$ banding is partially single-stranded, decreasing its mobility, as confirmed by studies of model substrates (Suppl. Fig. 4). The mobility of the slow-moving Y-like arcs (SMY), resulting from non-digestion at the restriction sites, is also modified by $\mathrm{CsCl}$ banding or by treatment with RNase $\mathrm{H}$ (mSMY). In the case of the BlpI digest of rat mtDNA, the changes to the mobility of the slow-moving Y-like arcs were subtler than for mouse mtDNA. However, both $\mathrm{CsCl}$ banding and $\mathrm{RNase} \mathrm{H}$ digestion generate a prominent sub-Y arc (sY). The maps indicate the digestion sites and relevant surrounding features of mouse and rat mtDNA (12S - 12S rRNA gene, NCR - non-coding region, Cyt b - cytochrome $b$ gene, grey bars) and location of the probe $\mathrm{r} 1$ (black bar). 


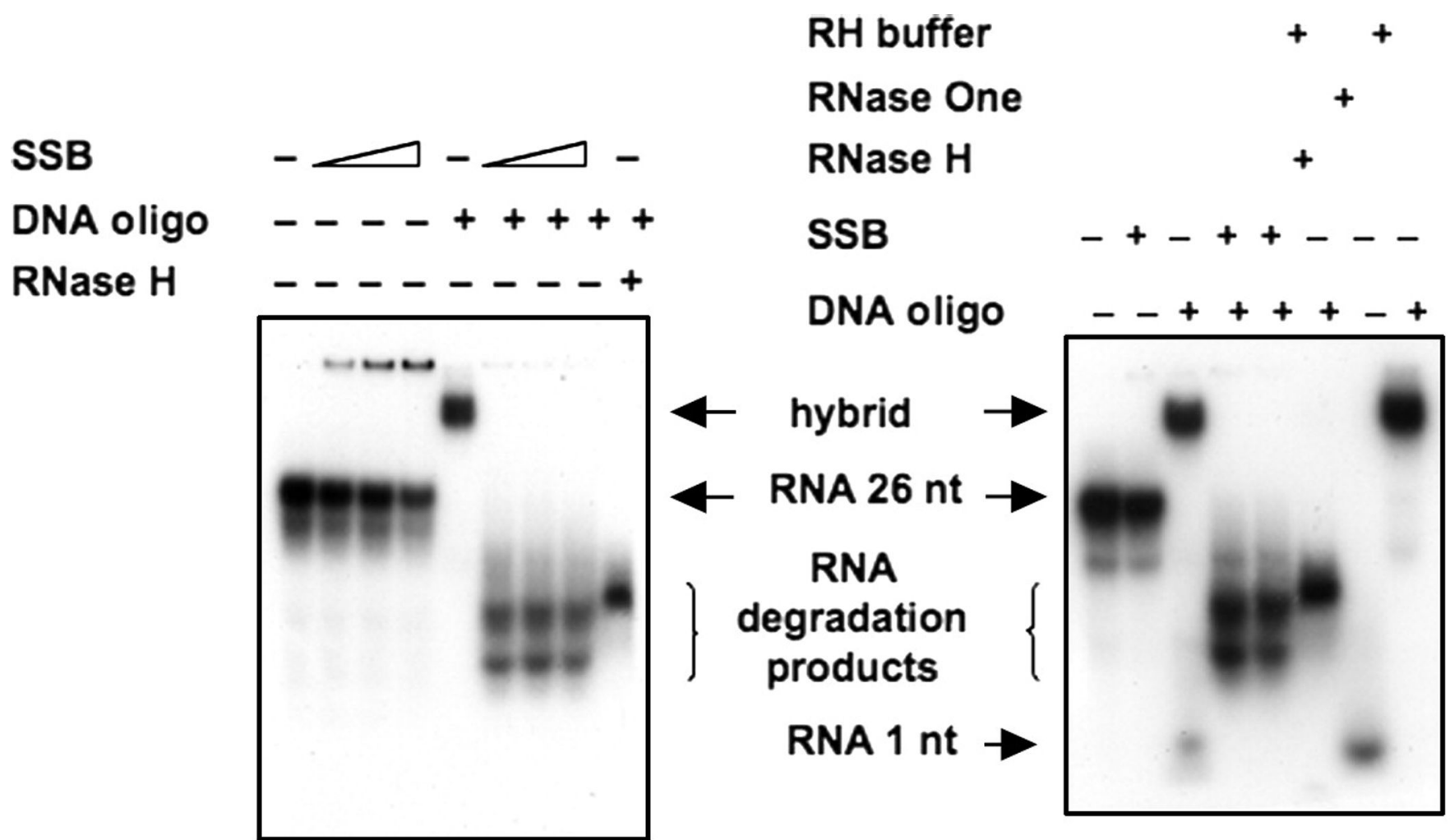

Figure 4. SSB exhibits an RNase H-like activity

Labeled RNA oligo alone, or annealed to the unlabelled DNA oligo, incubated with nucleases/buffers as shown or increasing amounts of SSB (GE Healthcare). For $100 \mathrm{ng}$ substrate nucleic acid, SSB was added at 230, 460 and $680 \mathrm{ng}$. In right-hand gel SSB was used at $680 \mathrm{ng}$. SSB from Promega yielded the same result (not shown). The residual fragment produced by RNase H digestion (or by SSB) was not a single nucleotide, since RNase One ${ }^{\mathrm{TM}}$ treatment produced a much smaller product, assumed to be mononucleotides. Note that Brown et al. (7) used SSB from GE Healthcare (formerly Amersham Biosciences) at 5-fold weight excess over mtDNA to prepare samples for AFM, similar to the intermediate condition used in the left-hand panel. 
(a) (b)

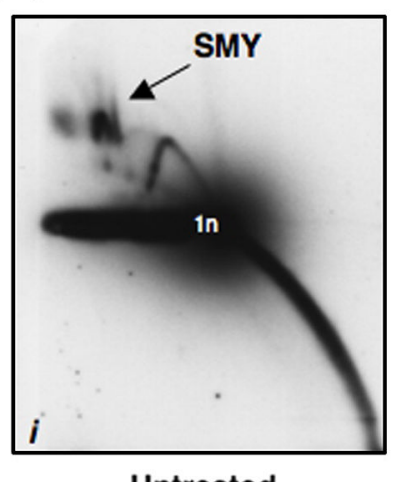

Untreated sucrose-gradient purified $\mathrm{mt}$

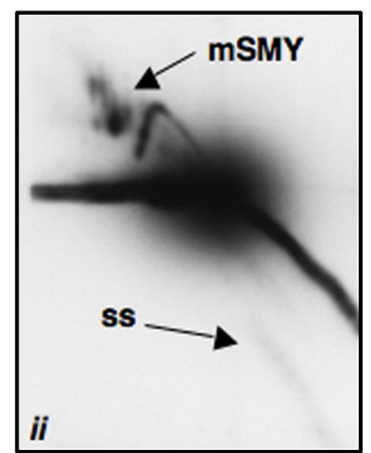

RNase H

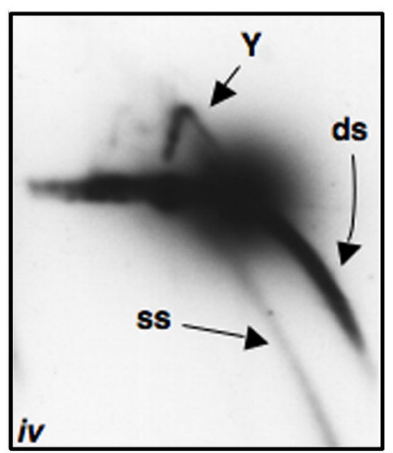

RNase H \& One

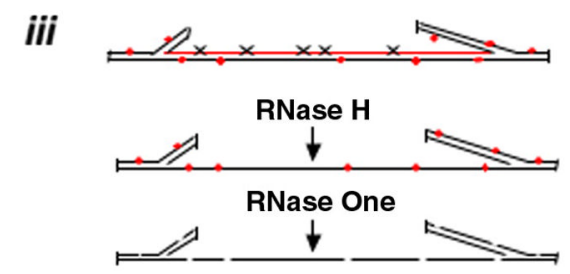

\section{(c) crude mt}
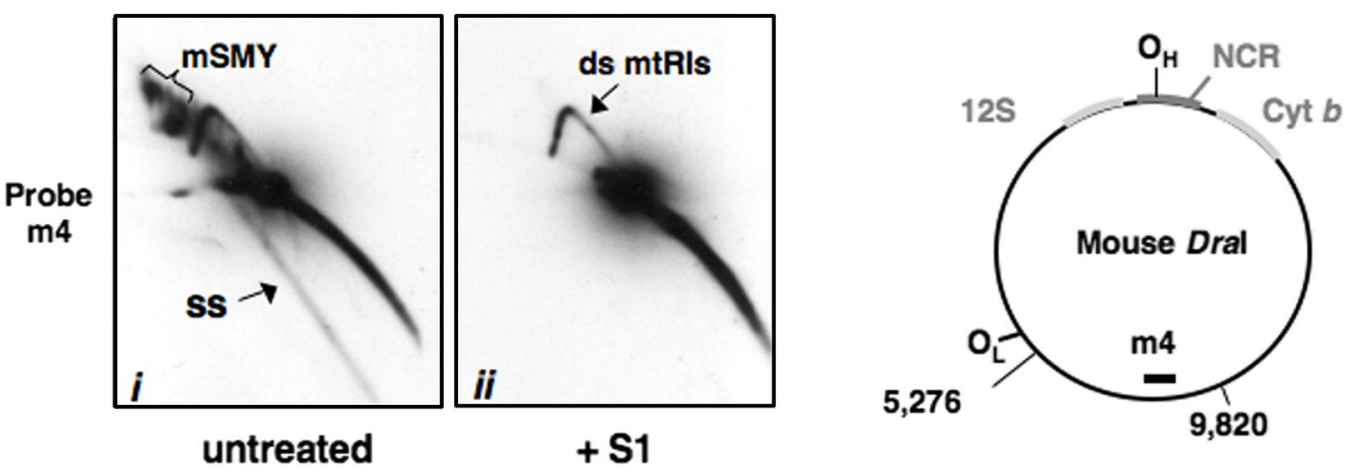

Figure 5. 2D-AGE analysis of single-stranded DNA molecules

A: End-labeled, heat-denatured (ss) and undenatured (ds) linear fragments (1 kb ladder, Invitrogen) were combined and separated by $2 \mathrm{D}$-AGE. The assignment of the various spots as double or single-stranded was based on heat-denatured and undenatured linear fragments run on separate $2 \mathrm{D}$ gels, in parallel (data not shown). The markers show the relative migration properties of arcs of double- and single-stranded DNAs under the gel conditions used in the experiments shown in the other panels. B: DraI-digested mtDNA from sucrose gradient-purified mouse liver mitochondria treated as indicated prior to 2D-AGE, and hybridized with probe $\mathrm{m} 4$. The fragment detected does not contain the origin, so the majority of mtRIs migrate as a standard Y-arc. No arc of ssDNA was seen, indicating that strand-separation of partially single-stranded molecules of the type predicted by the stranddisplacement model (SDM) either does not occur under these conditions, or that such molecules are absent. RNase $\mathrm{H}$ treatment (panel ii) was used deliberately to create molecular forms equivalent to those predicted by the SDM. The slow-moving Y-like arc was modified (mSMY), indicating the successful removal of tracts of lagging strand RNA, but only a very faint arc of ssDNA was created, showing that strand separation of partially single-stranded 
molecules is nevertheless minimal under these conditions. A combined RNase $\mathrm{H}$ plus RNase $\mathrm{One}^{\mathrm{TM}}$ treatment produced a more abundant arc of ssDNA fragments (panel B-iv), as the removal of the nascent RNA L-strand (red line) by RNase H exposes scattered ribonucleotides (red spots) on the template $\mathrm{H}$-strand to RNase One ${ }^{\mathrm{TM}}$ (panel B-iii). C: 2DAGE analysis of mtDNA molecules from crude mitochondria. DraI-digested liver mtDNA, with and without subsequent treatment by S1 nuclease prior to 2D-AGE, hybridized with probe $\mathrm{m} 4$. A schematic circular map of the mouse mitochondrial genome shows the positions of relevant $\mathrm{Dra \textrm {I }}$ sites, $\mathrm{O}_{\mathrm{H}}, \mathrm{O}_{\mathrm{L}}$, the probe used (black bar), the non-coding region (NCR, dark grey bar) and the genes for 12S rRNA and cytochrome $b$ (light grey bars). In addition to modified slow-moving arcs (mSMY), the non origin-containing fragment detected by probe $\mathrm{m} 4$ shows a standard $\mathrm{Y}$-arc resistant to $\mathrm{S} 1$ nuclease, plus an $\mathrm{S} 1$-sensitive sub-Y arc which is absent when DNA from highly purified mitochondria is analysed (panel B-i). mtRIs from crude mitochondria behave in this assay like intact mtDNA that has been treated with RNase H: only a faint ssDNA arc is visible, even though the modified SMY arcs contain single-stranded regions and are thus destroyed by S1 nuclease. In conclusion, strand-separation is not a viable explanation for the absence from 2D gels of the mtRIs predicted by the SDM. Moreover, the arcs that would be formed by single-stranded mtRIs are distinct from standard bubble arcs, based on model substrates (Suppl. Fig. 4), yet are not seen in material prepared from highly purified mitochondria. 
(a)

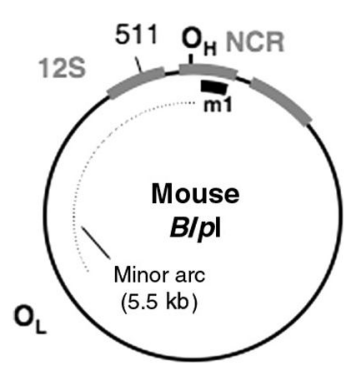

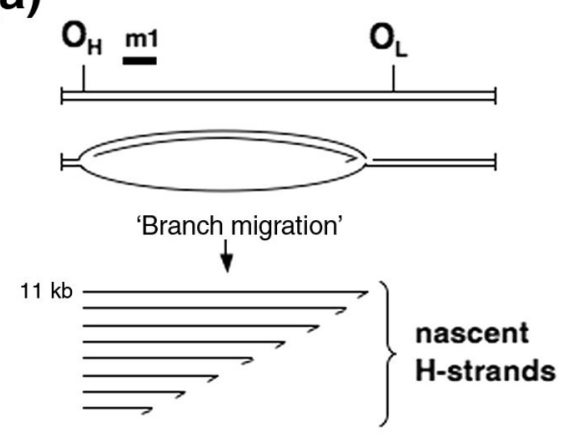

(b)
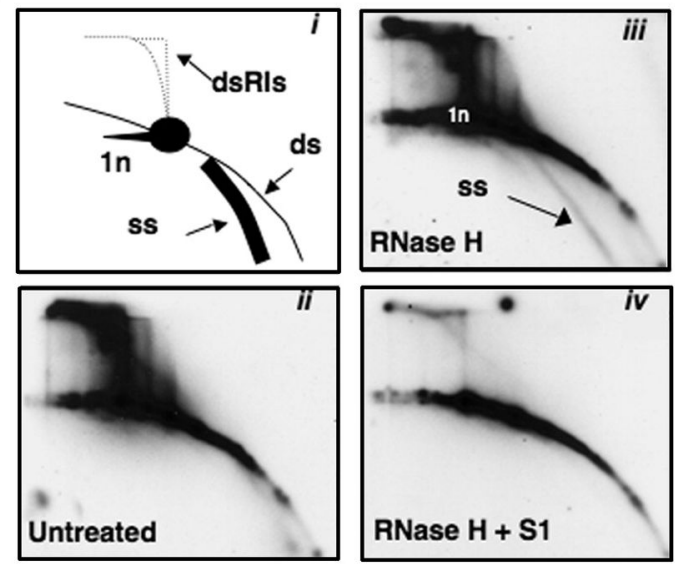

(c)
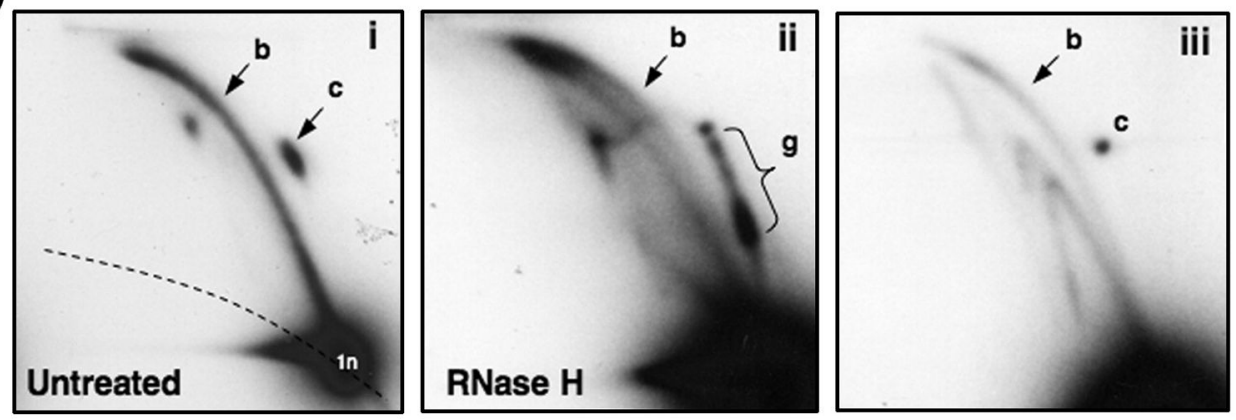

Figure 6. Full genome analysis of replicating mouse mtDNA by 2D-AGE

Strand separation of the partially single-stranded replication bubbles predicted by the SDM should generate a prominent, heterogeneous population of ssDNA molecules after 2D-AGE of $B l p I$ digested mouse mtDNA (panels A and B-i). The predicted ssDNA arc was not seen after hybridization to probe $\mathrm{m} 1$ (panel B-ii) unless the sample was treated with RNase $\mathrm{H}$ (panel B-iii). Note that the electrophoresis conditions used in this experiment do not resolve arcs associated with large fragments of DNA. A resolving gel of the same sample is shown in panel C: $\mathrm{i}$ - no further treatment. ii - treated with RNase $\mathrm{H}$ alone or iii - RNase $\mathrm{H}$ followed by $\mathrm{S} 1$ nuclease, after restriction digestion. $\mathrm{c}$ - circles; $\mathrm{g}$ - gapped circles; $\mathrm{b}$ - bubble arc. The map (top left) indicates the digestion site and relevant surrounding features of mouse mtDNA (12S - 12S rRNA gene, NCR - non-coding region) and location of the probe $\mathrm{m} 1$. As predicted by the RITOLS model, uncut circles which are resistant to digestion at the BlpI site are converted by RNase $\mathrm{H}$ treatment to an arc of gapped circles, indicating that noncutting at the BlpI site is due to the presence of lagging-strand RNA. The gapped circles are further digested (to linear molecules) by $\mathrm{S} 1$ nuclease, since the region that was originally RNA/DNA hybrid is left as ssDNA following RNase $\mathrm{H}$ treatment. 


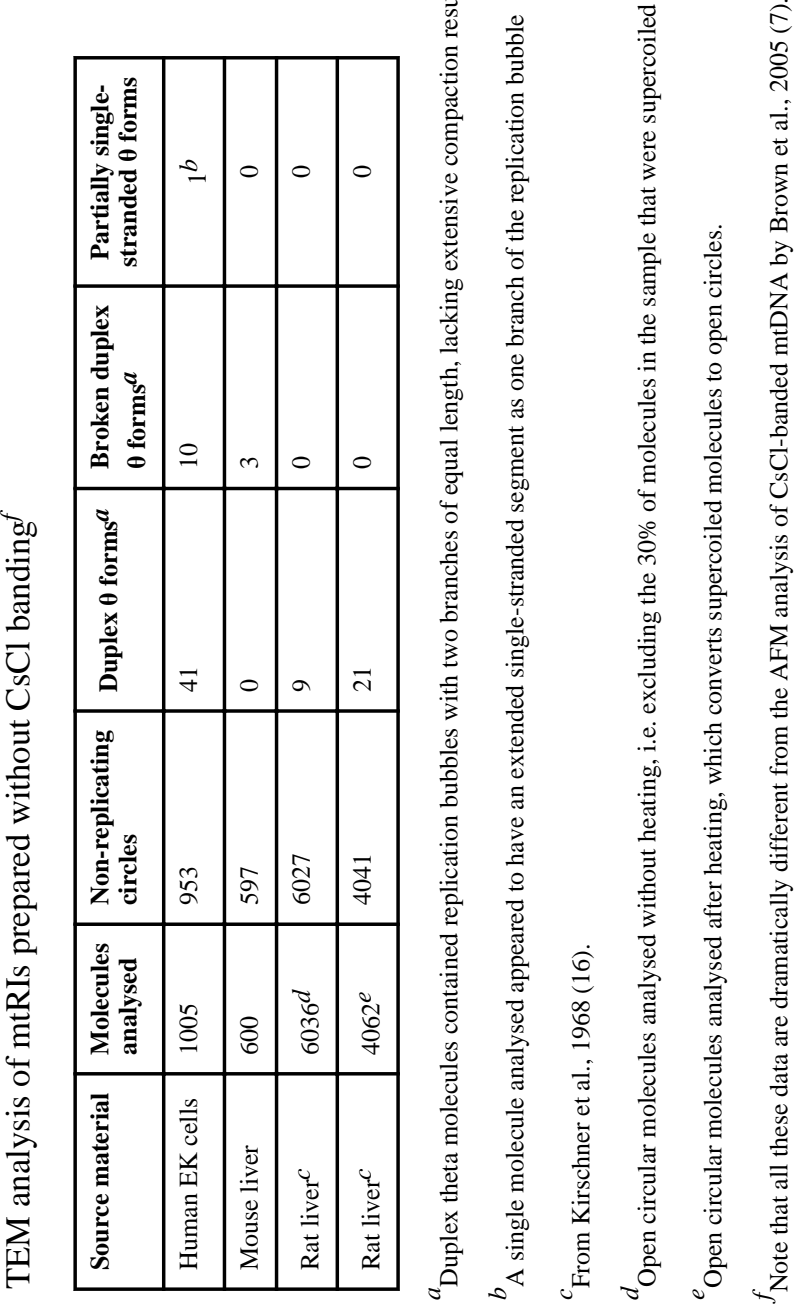

